\title{
Current research on the treatment of primary sclerosing cholangitis
}

\author{
Ahmad H Ali ${ }^{1, *}$, Elizabeth J Carey ${ }^{1}$, Keith D Lindor ${ }^{1,2}$ \\ ${ }^{1}$ Division of Gastroenterology and Hepatology, Mayo Clinic, Arizona, USA; \\ ${ }^{2}$ Arizona State University, College of Health Solutions, Phoenix, Arizona, USA.
}

\begin{abstract}
Summary Primary sclerosing cholangitis (PSC) is a progressive disease of the liver characterized by inflammation and destruction of the intra- and/or extra-hepatic bile ducts, leading to fibrosis and ultimately liver failure, cirrhosis and an increased risk of malignancy. The etiology of PSC is unclear. It is often associated with the inflammatory bowel diseases (IBD), particularly Ulcerative Colitis (UC); up to $75 \%$ of PSC patients have UC. PSC is more prevalent in men than in women. Ursodeoxycholic acid (UDCA) has been extensively studied in PSC in randomized clinical trials but failed to show a positive impact on the natural course of the disease. Currently, there is no effective medical therapy for PSC, and the majority of patients will eventually require liver transplantation. PSC is one of the leading indications for liver transplantation. In this paper, we review the current research on the potential therapeutic agents for the treatment of PSC.
\end{abstract}

Keywords: Primary sclerosing cholangitis, ursodeoxycholic acid, obeticholic acid, vancomycin

\section{Introduction}

Primary sclerosing cholangitis (PSC) is a progressive liver disease characterized by ongoing destruction of the intra- and extra-hepatic bile ducts leading to cholestasis, advanced fibrosis, liver cirrhosis and eventually liver failure with its consequent complications such as portal hypertension and an increased risk of malignancy (1-3). PSC affects nearly 50,000 patients in the United States (4). The median life expectancy after diagnosis of PSC is 12 to 18 years without liver transplantation $(3,5)$. PSC is often associated with Ulcerative Colitis (UC) (4), an inflammatory bowel disease (IBD) characterized by chronic ulceration of the large intestine. PSC can occur in association with autoimmune diseases such as autoimmune hepatitis and autoimmune pancreatitis; commonly referred to as the PSC overlap syndromes (6). The diagnosis of PSC is made in patients with a chronic cholestatic biochemical profile when cholangiography shows stricturing of the intra- and/or

Released online in J-STAGE as advance publication November 13, 2014.

*Address correspondence to:

Dr. Ahmad H Ali, Division of Gastroenterology and Hepatology, Mayo Clinic, 13400 East Shea Boulevard, Scottsdale, Arizona 85259, USA.

E-mail: ali.ahmad@mayo.edu; ahmad.ali@ttuhsc.edu extra-hepatic bile ducts (7). Small-duct PSC is a variant of PSC characterized by chronic cholestasis, normal cholangiography, and histological findings consistent with $\operatorname{PSC}(8,9)$.

Currently, there is no effective medical therapy for PSC. Ursodexoycholic acid (UDCA) is the single most extensively studied agent in PSC. Several controlled and uncontrolled clinical trials have shown significant improvement in liver biochemistries when PSC patients were treated with UDCA (10-15). However, large randomized and controlled prospective clinical trials have failed to demonstrate that UDCA can positively affect the clinical outcomes of patients with PSC $(13,15)$. In fact, the safety of long term use of high-dose UDCA in PSC patients has been questioned, as it has been associated with increased rates of serious adverse events $(13,16)$ and, more recently, with the development of colon cancer $(16,17)$. The American Association for the Study of Liver Disease (AASLD) recommends against the use of UDCA in PSC patients (7). Liver transplantation remains the treatment of choice for end-stage PSC, being the fifth leading indication for liver transplantation in the United States (18). In some Scandinavian countries, PSC is the leading indication for liver transplantation (18-20). Recurrent PSC is an important problem, occurring in the transplanted liver in $20 \%-40 \%$ of PSC patients (18).

Several potential therapeutic avenues in PSC have 
been explored over the last 2 decades, some of which have shown promising results. In this paper, we review the current research on the treatment strategies in PSC.

\section{Bile acid mimetics and PSC}

Twenty-four norUDCA is the C23 homolog of UDCA that is currently being evaluated in a phase II randomized clinical trial in patients with PSC (ClinicalTrials. gov Identifier: NCT01755507). In a rodent model of cholestasis, the administration of norUDCA to $M d r 2$ knockout mice improved sclerosing cholangitis, possibly by altering the composition of the bile acid pool through displacing the toxic bile acids and increasing the hydrophilicity of the bile acids (21). In a more recent animal model of cholestasis, norUDCA significantly improved indices of liver injury in common bile ductligated (CBDL) mice when compared to UDCA (22). Taken together, these results suggest that norUDCA could be of potential benefit in patients with PSC.

\section{Farnesoid X receptor agonists and PSC}

The farnesoid $\mathrm{X}$ receptors (FXRs) are a group of nuclear hormone receptors expressed in high amounts in tissues involved in bile acid metabolism such as liver, intestine, and kidney (23). Recently, bile acids have been identified as natural ligands of FXRs $(24,25)$. FXRs play a key role in bile acid homeostasis by regulation of genes involved in bile acid synthesis, secretion, conjugation, transportation, absorption, and detoxification (26-30). An important target of the FXRs is the gene encoding for cholesterol $7 \alpha$ hydroxylase (CYP7A1) the rate-limiting enzyme in bile acid biosynthesis. When bound to bile acids, FXRs repress the gene encoding for CYP7A1 (24). Moreover, the expression of an important transport protein (cytosolic intestinal bile acid-binding protein) (31) located in the intestines is increased as a result of activation of the FXRs $(24,32)$. This protein is believed to play a key role in the regulation of the enterohepatic circulation $(24,32)$. In addition to their role in bile acid homeostasis, FXRs have been found to regulate liver regeneration during liver injury (33-38).

Obeticholic acid (OCA, INT-747), a 6-ethyl derivative of the natural human bile acid chenodeoxycholic acid (CDCA), is a first-in-class selective FXR agonist with $\sim 100$-fold greater FXR agonistic activity than CDCA (39-41). In a male Wistar rat model of cholestasis, OCA protected hepatocytes against deleterious effects caused by administration of lithocholic acid (LCA) (41). In another animal model, the administration of OCA reduced liver fibrosis and indices of hepatic damage in bile duct ligated rats (42). Collectively, these results suggest that FXR agonists could be of therapeutic benefit in patients with cholestatic liver diseases.

The safety and efficacy of OCA has been evaluated in 2 randomized clinical trials in patients with primary biliary cirrhosis $(\mathrm{PBC})$ with promising results $(43,44)$. The administration of OCA to PBC patients led to a significant reduction of serum alkaline phosphatase (ALP), an important surrogate marker in $\operatorname{PBC}(43,44)$. One important adverse event was pruritus, occurring in a dose-dependent manner and leading to discontinuation of the drug in $38 \%$ of $\mathrm{PBC}$ patients $(43,44)$. Currently, a phase II clinical trial of OCA in PSC patients is ongoing, using lower doses to help avoid pruritus (ClinicalTrials.gov Identifier: NCT02177136).

\section{Apical sodium-dependent bile acid transporter inhibitors and PSC}

Abnormal bile acid pool composition is thought to play a key role in the pathogenesis and progression of PSC (45). This hypothesis is derived from several animal and human studies. PSC-like lesions occur in mice devoid of the canalicular transporter $M d r 2$, which mediates biliary excretion of phospholipids that normally form mixed micelles with the bile acids, thus protecting the liver against the detergent effects of bile acids (46). Bile acid toxicity towards the biliary epithelium could result from decreased biliary $\mathrm{HCO}_{3}$ secretion (47). The bile salt-sensing receptor TGR5 plays a key role in the regulation of $\mathrm{HCO}_{3}$ secretion, and interestingly, TGR5 has been identified as a likely disease gene in a large genome-wide study of PSC (48). In Lindor's high-dose UDCA study in PSC, treatment with high-dose UDCA was associated with an increased rate of serious clinical events when compared with placebo (13). Sinakos et al. investigated the serum bile acid composition in patients in the high-dose UDCA arm and compared that with serum bile acids in patients in the control group (49). They found a significant expansion of the total serum bile acid pool and increased UDCA and LCA enrichment in the UDCA-treated patients versus the placebo group when compared to pretreatment levels (49). In addition, they found that the increase in total serum bile acid pool correlated with worse outcomes in patients with PSC (49). Together, these observations suggest that changes in the bile acid pool could be deleterious in patients with PSC, and alteration of the bile acid pool may be of therapeutic benefit in PSC.

The apical sodium-dependent bile acid transporter (ASBT), also known as the ileal bile acid transporter, is expressed predominantly in the distal ileal tissue and plays a key role in the reabsorption of bile acids from the lumen of the small intestine, which is critical for the enterohepatic circulation of the bile acids (50). Normally, $\sim 95 \%$ of the secreted bile acids are reabsorbed from the intestine into the portal circulation and back to the liver (51). With this biological rationale, interrupting the enterohepatic circulation could result in a decrease bile acid load on the liver, which in turn could be of potential therapeutic benefit in patients with 
PSC. Currently a phase II clinical study evaluating the safety and efficacy of LUM001, an ASBT inhibitor, in patients with PSC is ongoing (ClinicalTrials.gov Identifier: NCT02061540).

\section{Antimicrobials and PSC}

Several animal experiments demonstrated a link between the gut microbiota and development of PSC (52-59). Induction of small bowel bacterial overgrowth by ligating the jejunum in rats resulted in development of hepatic lesions compatible with PSC $(53,55,56)$. Daily treatment with antibiotics led to significant improvement in these lesions (55), suggesting that gut microbiota modification could be of therapeutic benefit in a selected group of PSC patients.

Vancomycin, metronidazole and minocycline have been evaluated in clinical trials in patients with PSC $(60,61)$. The use of these antibiotics led to a significant reduction in serum ALP, an important surrogate marker in PSC $(60,61)$. Thus antibiotic therapy in PSC patients seems to be a promising tool in the treatment of PSC. However, larger studies are needed to clarify these results.

\section{Monoclonal antibodies and PSC}

Mucosal adressin cell adhesion molecule 1 (MAdCAM-1), an endothelial cell adhesion molecule, is expressed in high amounts in the gut of patients with IBD and those with IBD and PSC (62-65). Vascular adhesion protein 1 (VAP-1) has been found to induce the expression of MAdCAM-1 in the hepatic endothelial cells of human liver tissue (66). This, in turn, was associated with increased adhesion of lymphocytes from patients with PSC (66). Thus, targeting the VAP1/MAdCAM-1 could be of beneficial effect in patients with PSC. Vedolizumab is a monoclonal antibody against $\alpha 4 / \beta 7$, which is a cell surface glycoprotein expressed on $\mathrm{B}$ and $\mathrm{T}$ cells and interacts with MAdCAM-1, has shown a beneficial effect in UC (67). This agent could also be of therapeutic benefit in patients with PSC. The VAP-1-blocking agent, BTT1023, is currently being investigated in a phase II clinical trial in patients with PSC (ClinicalTrials.gov Identifier: NCT02239211).

It has been previously shown that the liverinfiltrating lymphocytes in PSC include mucosal T cells recruited to the liver by aberrant expression of the gutspecific chemokine CCL25 that activates $\alpha 4 / \beta 7$ binding to MAdCAM-1 on the hepatic endothelium $(63,68)$. Therefore, targeting the CCL25-MAdCAM-1 axis could be of therapeutic benefit in PSC. CCX282-B, a CCR9 antagonist that inhibits CCR9- and CCL25-dependent chemotaxis, has shown efficacy in Crohn's disease (69). This agent deserves to be investigated in patients with PSC.
Lysyl oxidase-like protein 2 (LOXL2) belongs to the lysyl oxidase family and has been shown to contribute to progressive liver damage in experimental models (70). Simtuzumab, a monoclonal antibody against LOXL2, is currently being investigated in a phase II clinical trial in patients with PSC (ClinicalTrials.gov Identifier: NCT01672853).

\section{Special cases}

Primary sclerosing cholangitis-Autoimmune hepatitis (PSC-AIH) overlap syndrome is a disorder characterized by clinical, biochemical and histological features of $\mathrm{AIH}$ in the presence of cholangiographic findings consistent with PSC $(71,72)$. Data on PSCAIH overlap patients are scarce and long-term outcome is not well-defined. Because of these reasons, there is no consensus on the treatment of patients with PSCAIH. Recently, Zenouzi et al. (73) reported the longterm follow up on three cases originally described in 1996. All three patients were alive $(22,27$, and 25 years after initial presentation) and have shown disease progression, two of whom are on the liver transplantation list (both developed esophageal varices and one developed weight loss). The third patient underwent liver transplantation 22 years after initial presentation. All three patients were on UDCA and immunosuppression therapy (azathioprine) (73). These data suggest that PSC-AIH may have a better prognosis than the classic PSC, and that the combination of UDCA and immunosuppression in PSC-AIH may be of therapeutic benefit and warrants investigation. Given the rarity of PSC-AIH, randomized clinical trials are unlikely to occur.

Autoimmune pancreatitis (AIP) is a chronic pancreatic condition characterized by narrowing of the pancreatic duct, raised immunoglobulin G4 (IgG4) levels, lymphocytic infiltration on biopsy, and response to steroids (74). AIP in association with intra-hepatic and/or extra-hepatic bile duct stricturing similar to those present in PSC is termed autoimmune pancreatitissclerosing cholangitis (AIP-SC) (7). It is unclear whether PSC and AIH represent different ends of the same disease or are separate clinical conditions. Patients with AIP-SC seem to respond to corticosteroids (75). However, studies are needed to clarify the long-term effects of corticosteroid therapy in patients with AIP$\mathrm{SC}$ which are unlikely to occur given the rarity of the disease.

\section{Conclusion}

PSC is progressive disease of the liver that ultimately leads to cirrhosis and liver failure. There is no effective medical therapy for PSC. Recent advances in understanding the pathological mechanisms that contribute to the hepatobiliary damage in PSC have 
led to the development of clinical programs to evaluate potential candidates as therapeutic tools in PSC. Several early-phase clinical trials evaluating these agents are underway.

\section{References}

1. Broomé U, Olsson R, Lööf L, Bodemar G, Hultcrantz R, Danielsson A, Prytz H, Sandberg-Gertzén H, Wallerstedt S, Lindberg G. Natural history and prognostic factors in 305 Swedish patients with primary sclerosing cholangitis. Gut. 1996; 38:610-615.

2. Farrant JM, Hayllar KM, Wilkinson ML, Karani J, Portmann BC, Westaby D, Williams R. Natural history and prognostic variables in primary sclerosing cholangitis. Gastroenterology. 1991; 100:1710-1717.

3. Wiesner RH, Grambsch PM, Dickson ER, Ludwig J, MacCarty RL, Hunter EB, Fleming TR, Fisher LD, Beaver SJ, LaRusso NF. Primary sclerosing cholangitis: Natural history, prognostic factors and survival analysis. Hepatology. 1989; 10:430-436.

4. Hirschfield GM, Karlsen TH, Lindor KD, Adams DH. Primary sclerosing cholangitis. Lancet. 2013; 382:15871599.

5. Ponsioen CY, Vrouenraets SM, Prawirodirdjo W, Rajaram R, Rauws EA, Mulder CJ, Reitsma JB, Heisterkamp SH, Tytgat GN. Natural history of primary sclerosing cholangitis and prognostic value of cholangiography in a Dutch population. Gut. 2002; 51:562-566.

6. Gohlke F, Lohse AW, Dienes HP, Löhr H, MärkerHermann E, Gerken G, Meyer zum Büschenfelde KH. Evidence for an overlap syndrome of autoimmune hepatitis and primary sclerosing cholangitis. J Hepatol. 1996; 24:699-705.

7. Chapman R, Fevery J, Kalloo A, Nagorney DM, Boberg KM, Shneider B, Gores GJ; American Association for the Study of Liver Diseases. Diagnosis and management of primary sclerosing cholangitis. Hepatology. 2010; 51:660-678.

8. Olsson R, Glaumann H, Almer S, Broomé U, Lebrun B, Bergquist A, Björnsson E, Prytz H, Danielsson A,Lindgren S. High prevalence of small duct primary sclerosing cholangitis among patients with overlapping autoimmune hepatitis and primary sclerosing cholangitis. Eur J Intern Med. 2009; 20:190-196.

9. Björnsson E, Olsson R, Bergquist A, Lindgren S, Braden B, Chapman RW, Boberg KM, Angulo P. The natural history of small-duct primary sclerosing cholangitis. Gastroenterology. 2008; 134:975-980.

10. Beuers U, Spengler U, Kruis W, Aydemir U, Wiebecke B, Heldwein W, Weinzierl M, Pape GR, Sauerbruch T, Paumgartner G. Ursodeoxycholic acid for treatment of primary sclerosing cholangitis: A placebo-controlled trial. Hepatology. 1992; 16:707-714.

11. Chazouillères O, Poupon R, Capron JP, Metman EH, Dhumeaux D, Amouretti M, Couzigou P, Labayle D, Trinchet JC. Ursodeoxycholic acid for primary sclerosing cholangitis. J Hepatol. 1990; 11:120-123.

12. Lindor KD. Ursodiol for primary sclerosing cholangitis. Mayo Primary Sclerosing Cholangitis-Ursodeoxycholic Acid Study Group. N Engl J Med. 1997; 336:691-695.

13. Lindor KD, Kowdley KV, Luketic VA, et al. Highdose ursodeoxycholic acid for the treatment of primary sclerosing cholangitis. Hepatology. 2009; 50:808-814.

14. Mitchell SA, Bansi DS, Hunt N, Von Bergmann K, Fleming KA, Chapman RW. A preliminary trial of high-dose ursodeoxycholic acid in primary sclerosing cholangitis. Gastroenterology. 2001; 121:900-907.

15. Olsson R, Boberg KM, de Muckadell OS, et al. Highdose ursodeoxycholic acid in primary sclerosing cholangitis: A 5-year multicenter, randomized, controlled study. Gastroenterology. 2005; 129:1464-1472.

16. Imam MH, Sinakos E, Gossard AA, Kowdley KV, Luketic VA, Edwyn Harrison M, McCashland T, Befeler AS,Harnois D, Jorgensen R, Petz J, Keach J, DeCook AC, Enders F, Lindor KD. High-dose ursodeoxycholic acid increases risk of adverse outcomes in patients with early stage primary sclerosing cholangitis. Aliment Pharmacol Ther. 2011; 34:1185-1192.

17. Eaton JE, Silveira MG, Pardi DS, Sinakos E, Kowdley KV, Luketic VA, Harrison ME, McCashland T, Befeler AS,Harnois D, Jorgensen R, Petz J, Lindor KD. Highdose ursodeoxycholic acid is associated with the development of colorectal neoplasia in patients with ulcerative colitis and primary sclerosing cholangitis. Am J Gastroenterol. 2011; 106:1638-1645.

18. Bjoro K, Brandsaeter B, Foss A, Schrumpf E. Liver transplantation in primary sclerosing cholangitis. Semin Liver Dis. 2006; 26:69-79.

19. Brandsaeter B, Broomé U, Isoniemi H, Friman S, Hansen B, Schrumpf E, Oksanen A, Ericzon BG, Höckerstedt K, Mäkisalo H, Olsson R, Olausson M, Kirkegaard P, Bjøro K. Liver transplantation for primary sclerosing cholangitis in the Nordic countries: Outcome after acceptance to the waiting list. Liver Transpl. 2003; 9:961-969.

20. Brandsaeter B, Friman S, Broomé U, Isoniemi H, Olausson M, Bäckman L, Hansen B, Schrumpf E, Oksanen A,Ericzon BG, Höckerstedt K, Mäkisalo $\mathrm{H}$, Kirkegaard P, Bjøro K. Outcome following liver transplantation for primary sclerosing cholangitis in the Nordic countries. Scand J Gastroenterol. 2003; 38:11761183 .

21. Fickert P, Wagner M, Marschall HU, Fuchsbichler A, Zollner G, Tsybrovskyy O, Zatloukal K, Liu J, Waalkes MP,Cover C, Denk H, Hofmann AF, Jaeschke H, Trauner M. 24-norUrsodeoxycholic acid is superior to ursodeoxycholic acid in the treatment of sclerosing cholangitis in Mdr2 (Abcb4) knockout mice. Gastroenterology. 2006; 130:465-481.

22. Fickert P, Pollheimer MJ, Silbert D, Moustafa T, Halilbasic E, Krones E, Durchschein F, Thüringer A, Zollner G,Denk H, Trauner M. Differential effects of norUDCA and UDCA in obstructive cholestasis in mice. J Hepatol. 2013; 58:1201-1208.

23. Forman BM, Goode E, Chen J, Oro AE, Bradley DJ, Perlmann T, Noonan DJ, Burka LT, McMorris T, Lamph WW, Evans RM, Weinberger C. Identification of a nuclear receptor that is activated by farnesol metabolites. Cell. 1995; 81:687-693.

24. Makishima M, Okamoto AY, Repa JJ, Tu H, Learned RM, Luk A, Hull MV, Lustig KD, Mangelsdorf DJ, Shan B. Identification of a nuclear receptor for bile acids. Science. 1999; 284:1362-1365.

25. Wang H, Chen J, Hollister K, Sowers LC, Forman BM. Endogenous bile acids are ligands for the nuclear receptor FXR/BAR. Mol Cell. 1999; 3:543-553.

26. Cariou B, Staels B. FXR: A promising target for the 
metabolic syndrome? Trends Pharmacol Sci. 2007; 28:236-243.

27. Edwards PA, Kast HR, Anisfeld AM. BAREing it all: The adoption of LXR and FXR and their roles in lipid homeostasis. J Lipid Res. 2002; 43:2-12.

28. Li J, Pircher PC, Schulman IG, Westin SK. Regulation of complement $\mathrm{C} 3$ expression by the bile acid receptor FXR. J Biol Chem. 2005; 280:7427-7434.

29. Sinal CJ, Tohkin M, Miyata M, Ward JM, Lambert G, Gonzalez FJ. Targeted disruption of the nuclear receptor FXR/BAR impairs bile acid and lipid homeostasis. Cell. 2000; 102:731-744.

30. Zhang Y, Castellani LW, Sinal CJ, Gonzalez FJ, Edwards PA. Peroxisome proliferator-activated receptor-gamma coactivator 1alpha (PGC-1alpha) regulates triglyceride metabolism by activation of the nuclear receptor FXR. Genes Dev. 2004; 18:157-169.

31. Kanda T, Foucand L, Nakamura Y, Niot I, Besnard P, Fujita M, Sakai Y, Hatakeyama K, Ono T, Fujii H. Regulation of expression of human intestinal bile acidbinding protein in Caco-2 cells. Biochem J. 1998; 330:261-265.

32. Gong YZ, Everett ET, Schwartz DA, Norris JS, Wilson FA. Molecular cloning, tissue distribution, and expression of a 14-kDa bile acid-binding protein from rat ileal cytosol. Proc Natl Acad Sci U S A 1994; 91:47414745.

33. Huang W, Ma K, Zhang J, Qatanani M, Cuvillier J, Liu J, Dong B, Huang X, Moore DD. Nuclear receptordependent bile acid signaling is required for normal liver regeneration. Science. 2006; 312:233-236.

34. Goldfarb M. Signaling by fibroblast growth factors: The inside story. Sci STKE. 2001; 2001:pe37.

35. Holt JA, Luo G, Billin AN, Bisi J, McNeill YY, Kozarsky KF, Donahee M, Wang DY, Mansfield TA, Kliewer SA, Goodwin B, Jones SA. Definition of a novel growth factor-dependent signal cascade for the suppression of bile acid biosynthesis. Genes Dev. 2003; 17:1581-1591.

36. Ornitz DM, Itoh N. Fibroblast growth factors. Genome Biol. 2001; 2:REVIEWS3005.

37. Song KH, Ellis E, Strom S, Chiang JY. Hepatocyte growth factor signaling pathway inhibits cholesterol 7alpha-hydroxylase and bile acid synthesis in human hepatocytes. Hepatology. 2007; 46:1993-2002.

38. Zhang L, Huang X, Meng Z, Dong B, Shiah S, Moore DD, Huang W. Significance and mechanism of CYP7al gene regulation during the acute phase of liver regeneration. Mol Endocrinol. 2009; 23:137-145.

39. Adorini L, Pruzanski M, Shapiro D. Farnesoid X receptor targeting to treat nonalcoholic steatohepatitis. Drug Discov Today. 2012; 17:988-997.

40. Pellicciari R, Costantino G, Camaioni E, Sadeghpour BM, Entrena A, Willson TM, Fiorucci S, Clerici C, Gioiello A. Bile acid derivatives as ligands of the farnesoid X receptor. Synthesis, evaluation, and structure-activity relationship of a series of body and side chain modified analogues of chenodeoxycholic acid. J Med Chem. 2004; 47:4559-4569.

41. Pellicciari R, Fiorucci S, Camaioni E, Clerici C, Costantino G, Maloney PR, Morelli A, Parks DJ, Willson TM. 6alpha-ethyl-chenodeoxycholic acid (6-ECDCA), a potent and selective FXR agonist endowed with anticholestatic activity. J Med Chem. 2002; 45:35693572.

42. Fiorucci S, Antonelli E, Rizzo G, Renga B, Mencarelli
A, Riccardi L, Orlandi S, Pellicciari R, Morelli A. The nuclear receptor SHP mediates inhibition of hepatic stellate cells by FXR and protects against liver fibrosis. Gastroenterology. 2004; 127:1497-1512.

43. Mason A, Luketic VA, Lindor KD, et al. Farnesoid-X receptor agonists: A new class of drugs for the treatment of PBC? An international study evaluating the addition of INT-747 to ursodeoxycholic acid. J Hepatol. 2010; 52(Suppl 1):S1-S2.

44. Kowdley KV, Jones D, Luketic V, et al. An international study evaluating the farnesoid $\mathrm{X}$ receptor agonist obeticholic acid as monotherapy in PBC. J Hepatol. 2011; 54:S13.

45. Chazouilleres O. Primary sclerosing cholangitis and bile acids. Clin Res Hepatol Gastroenterol. 2012; 36 (Suppl 1):S21-S25.

46. Fickert P, Fuchsbichler A, Wagner M, Zollner G, Kaser A, Tilg H, Krause R, Lammert F, Langner C, Zatloukal K, Marschall HU, Denk H,Trauner M. Regurgitation of bile acids from leaky bile ducts causes sclerosing cholangitis in $M d r 2$ ( $A b c b 4)$ knockout mice. Gastroenterology. 2004; 127:261-274.

47. Beuers U, Hohenester S, de Buy Wenniger LJ, Kremer AE, Jansen PL, Elferink RP. The biliary $\mathrm{HCO}_{3}$ - umbrella: A unifying hypothesis on pathogenetic and therapeutic aspects of fibrosing cholangiopathies. Hepatology. 2010; 52:1489-1496.

48. Karlsen TH, Franke A, Melum E, et al. Genome-wide association analysis in primary sclerosing cholangitis. Gastroenterology. 2010; 138:1102-1111.

49. Sinakos E, Marschall HU, Kowdley KV, Befeler A, Keach J, Lindor K. Bile acid changes after high-dose ursodeoxycholic acid treatment in primary sclerosing cholangitis: Relation to disease progression. Hepatology. 2010; 52:197-203.

50. Chen L, Yao X, Young A, McNulty J, Anderson D, Liu Y, Nystrom C, Croom D, Ross S, Collins J, Rajpal D, Hamlet K, Smith C, Gedulin B. Inhibition of apical sodium-dependent bile acid transporter as a novel treatment for diabetes. Am J Physiol Endocrinol Metab. 2012; 302:E68-E76.

51. Meier PJ, Stieger B. Bile salt transporters. Annu Rev Physiol. 2002; 64:635-661.

52. Aron JH, Bowlus CL. The immunobiology of primary sclerosing cholangitis. Semin Immunopathol. 2009; 31:383-397.

53. Lichtman SN, Keku J, Clark RL, Schwab JH, Sartor RB. Biliary tract disease in rats with experimental small bowel bacterial overgrowth. Hepatology. 1991; 13:766772 .

54. Lichtman SN, Keku J, Schwab JH, Sartor RB. Evidence for peptidoglycan absorption in rats with experimental small bowel bacterial overgrowth. Infect Immun. 1991; 59:555-562.

55. Lichtman SN, Keku J, Schwab JH, Sartor RB. Hepatic injury associated with small bowel bacterial overgrowth in rats is prevented by metronidazole and tetracycline. Gastroenterology. 1991; 100:513-519.

56. Lichtman SN, Okoruwa EE, Keku J, Schwab JH, Sartor RB. Degradation of endogenous bacterial cell wall polymers by the muralytic enzyme mutanolysin prevents hepatobiliary injury in genetically susceptible rats with experimental intestinal bacterial overgrowth. J Clin Invest. 1992; 90:1313-1322.

57. Pollheimer MJ, Halilbasic E, Fickert P, Trauner M. 
Pathogenesis of primary sclerosing cholangitis. Best Pract Res Clin Gastroenterol. 2011; 25:727-739.

58. Tabibian JH, O'Hara SP, Larusso NF. Primary sclerosing cholangitis: The gut-liver axis. Clin Gastroenterol Hepatol. 2012; 10:819; author reply 819-820.

59. Worthington J, Cullen S, Chapman R. Immunopathogenesis of primary sclerosing cholangitis. Clin Rev Allergy Immunol. 2005; 28:93-103.

60. Silveira MG, Torok NJ, Gossard AA, Keach JC, Jorgensen RA, Petz JL, Lindor KD. Minocycline in the treatment of patients with primary sclerosing cholangitis: Results of a pilot study. Am J Gastroenterol. 2009; 104:83-88.

61. Tabibian JH, Weeding E, Jorgensen RA, Petz JL, Keach JC, Talwalkar JA, Lindor KD. Randomised clinical trial: Vancomycin or metronidazole in patients with primary sclerosing cholangitis - a pilot study. Aliment Pharmacol Ther. 2013; 37:604-612.

62. Briskin M, Winsor-Hines D, Shyjan A, Cochran N, Bloom S, Wilson J, McEvoy LM, Butcher EC, Kassam N, Mackay CR, Newman W, Ringler DJ. Human mucosal addressin cell adhesion molecule- 1 is preferentially expressed in intestinal tract and associated lymphoid tissue. Am J Pathol. 1997; 151:97-110.

63. Eksteen B, Miles AE, Grant AJ, Adams DH. Lymphocyte homing in the pathogenesis of extra-intestinal manifestations of inflammatory bowel disease. Clin Med. 2004; 4:1731-1780.

64. Grant AJ, Lalor PF, Hubscher SG, Briskin M, Adams DH. MAdCAM-1 expressed in chronic inflammatory liver disease supports mucosal lymphocyte adhesion to hepatic endothelium (MAdCAM-1 in chronic inflammatory liver disease). Hepatology. 2001; 33:10651072.

65. Hillan KJ, Hagler KE, MacSween RN, Ryan AM, Renz ME, Chiu HH, Ferrier RK, Bird GL, Dhillon AP, Ferrell LD, Fong S. Expression of the mucosal vascular addressin, MAdCAM-1, in inflammatory liver disease. Liver. 1999; 19:509-518.

66. Liaskou E, Karikoski M, Reynolds GM, Lalor PF, Weston CJ, Pullen N, Salmi M, Jalkanen S, Adams DH. Regulation of mucosal addressin cell adhesion molecule
1 expression in human and mice by vascular adhesion protein 1 amine oxidase activity. Hepatology. 2011; 53:661-672.

67. Feagan BG, Rutgeerts P, Sands BE, et al. Vedolizumab as induction and maintenance therapy for ulcerative colitis. N Engl J Med. 2013; 369:699-710.

68. Eksteen B, Grant AJ, Miles A, Curbishley SM, Lalor PF, Hübscher SG, Briskin M, Salmon M, Adams DH. Hepatic endothelial CCL25 mediates the recruitment of CCR9+ gut-homing lymphocytes to the liver in primary sclerosing cholangitis. J Exp Med. 2004; 200:1511-1517.

69. Keshav S, Vanasek T, Niv Y, et al. A randomized controlled trial of the efficacy and safety of CCX282-B, an orally-administered blocker of chemokine receptor CCR9, for patients with Crohn's disease. PLoS One. 2013; 8:e60094.

70. Vadasz Z, Kessler O, Akiri G, Gengrinovitch S, Kagan HM, Baruch Y, Izhak OB, Neufeld G. Abnormal deposition of collagen around hepatocytes in Wilson's disease is associated with hepatocyte specific expression of lysyl oxidase and lysyl oxidase like protein-2. J Hepatol. 2005; 43:499-507.

71. Alvarez F, Berg PA, Bianchi FB, et al. International Autoimmune Hepatitis Group Report: Review of criteria for diagnosis of autoimmune hepatitis. J Hepatol. 1999; 31:929-938.

72. Beuers U, Rust C. Overlap syndromes. Semin Liver Dis. 2005; 25:311-320.

73. Zenouzi R, Lohse AW. Long-term outcome in PSC/AIH "overlap syndrome": Does immunosuppression also treat the PSC component? J Hepatol. 2014; 61:1189-1191.

74. Kamisawa T, Egawa N, Tsuruta K, Okamoto A, Funata N. Primary sclerosing cholangitis may be overestimated in Japan. J Gastroenterol. 2005; 40:318-319.

75. Nakazawa T, Ohara H, Sano H, Ando T, Aoki S, Kobayashi S, Okamoto T, Nomura T, Joh T, Itoh M. Clinical differences between primary sclerosing cholangitis and sclerosing cholangitis with autoimmune pancreatitis. Pancreas. 2005; 30:20-25.

(Received October 11, 2014; Revised November 10, 2014; Accepted November 11, 2014) 